\title{
The Shipping Feasibility in Indonesian Waters is Supported by Predictors based on Expert System and Information Systems of Android
}

\author{
Syamsul Arifina,"* and Aulia Siti Aisjah ${ }^{b}$ \\ Department of Engineering Physics, Institut Teknologi Sepuluh Nopember (ITS), Surabaya, \\ Indonesia \\ a.syamp3ai@its.ac.id; syamp3ai@gmail.com,b.auliasa@ep.its.ac.id; auliasa20@gmail.com \\ *corresponding author
}

Keywords: android, Fuzzy Type II, Indonesia waters, information system, maritime weather, predictors, sea transportation users.

Abstract: Maritime weather information system is needed by the Indonesian fishermen and sea transportation users. The system has been designed to be able to provide in present and in the future information in high accuracy. The system connects directly to the database of mobile phone fishermen. The system consists of several sub-systems that are capable of processing and analyzing data from the buoy weather stations, predict in several hours in the later. Predictors designed in various expert methods, which were based on fuzzy and neural network. The predictor results in the highest accuracy when it was used of Fuzzy Type II. Testing the system was done in many waters in East Java, and Surabaya-Banjarmasin sea line. The longest time the information received by the fisherman is 20 seconds since it is sent by maritime station data server, and it is not losses data.

\section{Introduction}

The number of fishermen in Indonesia is almost 4 million people, according to the secretariat of the Vice President Indonesia in 2011, and the number of residents who depend on this life is more than 6 million according to FAO report in 2011 [1]. The life of fishermen in any country in the world will be in desperate need of information about the information of marine weather. Some countries have developed information systems for fishermen, ie Malaysia, India, Kenya, Africa, and others [2], [3], [4]. Information systems of weather conditions and predictions in many hours later, not only for fishermen, but also for other marine users, ie tourists, and inter-island transportation. Indonesia is one of the developing countries which is almost of all traditional fishermen use mobile phones for their communication purposes.

The coastline length in Indonesia is $81,000 \mathrm{~km}$. This is the fourth longest in the world. This condition requires a communication media to facilitate the broadcast of maritime information especially to the fishermen [5], [6]. The traditional fishermen use boats on less than $30 \mathrm{GT}$. They have a sailing ranges is not too long from the coastline and in maximum coverage of 12 miles. The most vessel are not equipped with safety and security systems [7].

Study of information and predictor systems are related with marine weather measurements has been carried out in over the years. The continuing research is developed to produce the overall system 
in reliable, accurate and usage in a longer data transmission coverage [8]. The system consists of: (1) a floating object in buoy weather, (2) sensors for measuring the marine weather variables are mounted on (1), (3) a server in ground station for receiving and recording maritime weather data, encoded system, and predictor system, (4) information systems are send data to users [9], [1].

The sub-system of (1) above, is a cylindrical pile form with a bottom side diameter of $40 \mathrm{~cm}$ and the height of $60 \mathrm{~cm}$, and an upper diameter of $160 \mathrm{~cm}$ and the height of $25 \mathrm{~cm}$. Buoy weather has been tested in static and dynamic stability. The development of existing model is done by modeling simulation uses of Particle Swarm Optimization (PSO) method. The aim is higher reliability for the usage in the higher sea state [10]. Sub-system of (2) is consists of several sensors, ie: air temperature, air pressure, humidity, direction and speed of wind, and sea currents. The five sensors are measure the maritime weather data in the time $t$ [9]. The sub-system of (3) consists of data acquisition and predictor systems. The measurement variables used for prediction in the future, ie the magnitude of the sea current, wind speed and significant wave height. Weather predictors are designed in several methods. The objectives are obtain the highest predictor accuracy. Sub system of (4) is an information system that is connected to the data base system of fishermen mobile phones.

The accuracy of the predictor depends on the predict methods. The method known as classical forecasting is based on periodic series data weather. Several methods are developed on an empirical basis ie: AR (Auto Regresive), ARMA (Auto Regresive Moving Average), ARIMA (Auto Regresive Integrated Moving Average), ARMAX (Auto Regresive Moving Average Exogeneus), and others [11]. The weakness method in forecast process is need a big number of data size. This sample should represent the characteristics of population as weather conditions. Two expertise-based methods as alternative, that are the artificial neural networks and fuzzy logic. The methods have been implemented on weather stations as predictors in Java Sea.

The fuzzy predictors as predictor of significant wave height in the later use the rules as a function of the present and previous values. The data is significant wave height and sea current. The accuracy of predictor is too small, that is in average of 59.20\% [12]. This fuzzy method was re-developed by combining with numerical method. The Lagrange and Newton Raphson interpolation as two numerical methods for calculate the output of fuzzy predictor in the other latitude and longitude position. The both methods give accuracy in almost the same of $72.6 \%$ [13]. The strategy for improving accuracy is add other input variables ie: speed and direction of wind [14].

\section{Method}

This research is conducted in several phase. Phase 1 that is: designing hardware in sea station, designing data receiver, processer, predictor, and information system in server of the ground station [1]. The predictor on the ground server is developed in various methods. Phase 2 is designing software for several function as a recorder, processor, predictor, as well as a weather information system for marine users.

\subsection{Maritime Weather Predictor}

The Figure 1 is a block diagram of marine weather predictor system.

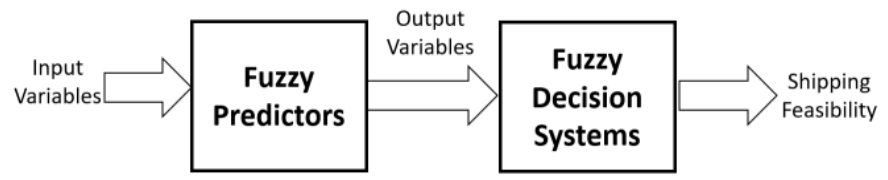

Figure 1: Block diagram of fuzzy maritime predictor system 
The variable inputs in predictor of Figure. 1 are: speed and direction of wind, sea current, and the significant wave height in the present and in previous time. The output variables are: significant wave height, wind speed, and sea current in the later. The wind and current on surface sea have a linear correlation [12].

The fuzzy system is fuzzy type 1 as a predictor consists of three sub-systems, namely: fuzzification, inference, and output processing or defuzzification [15]. Fuzzy type 2 has different characteristics to fuzzy type 1. In the output processing consists of two units, namely: unit reduction and defuzzification. The form of membership function in fuzzy type 2 is more flexible than type 1, because its membership function has two degrees of membership [16]. The form of fuzzy membership function of significant wave height is Gaussian, trapezoidal form of current and wind speed. Fuzzy system predicts of output variables in some rules in following function,

- The predictor of significant wave height,

$$
H s(t+1)=f(t, V w(t-2), V w(t-1), V w(t), H s(t-2), H s(t-1), H s(t))
$$

- The predictor of sea current,

$$
C u(t+1)=g(t, V w(t), C u(t-2), C u(t-1), C u(t)
$$

- The predictor of wind,

$$
V a(t=1)=h(t, V w(t-2), V w(t-1), V w(t))
$$

Where, $\mathrm{t}$ : time in the present, $\mathrm{g}(.$.$) is a function of variables \mathrm{Vw}=$ Wind speed, $\mathrm{Hs}=$ significance wave height, $\mathrm{Cu}=$ ocean current, $\mathrm{t}-\mathrm{i}=$ time in the $\mathrm{i}$ hour before $\mathrm{t}$.

The rules of Fuzzy Predictors use If... Then rules as equation of (1), (2) and (3).

The three variables in above are transformed into fuzzy variables in the fuzzification process. The membership function of significant wave height is expressed in seven, namely: Glassy, Rippled, Wavelets, Slight, Moderate, Rough, and Very Rough. The wind speed is expressed in seven functions, namely: Calm, Light Water, Light Breeze, Gentle Breeze, Moderate Breeze, Fresh Breeze and strong Breeze. Both variables are classified in accordance to WMO standards [17]. The membership function of sea current is expressed in seven, namely: Very Slow, Slow, Smooth, Slight, Average, Fast, Very Fast [12].

\subsection{Fuzzy Decision of Shipping Feasibility}

The output variables of fuzzy predictor as input for decision-making system of shipping feasibility. The shipping feasibility is determined by the tonnage of the ship and the sea weather conditions, ie wave height and ocean currents. Navigation board of Tanjung Perak port Surabaya provides recommendation of shipping feasibility is depend on sea conditions, as Table 1 below [18]. The decision-making of shipping feasibility system uses a look up table that corresponds to the rules in Table 1. 
Table 1: The Recommendation of Shipping Feasibility (Tanjung Perak Port Authority of Shipping)

\begin{tabular}{|c|c|c|}
\hline Gross Tonnage (GT) & Significant wave height (sea state) & Sea current \\
\hline $1-7 \mathrm{GT}$ & Wavelets (2) & Smooth \\
\hline $7-175 \mathrm{GT}$ & Slight (3) & Slight \\
\hline $175-500 \mathrm{GT}$ & Moderate (4) & Average \\
\hline $500-5000 \mathrm{GT}$ & Rough (5) & Fast \\
\hline $500-10000 \mathrm{GT}$ & Very Rough (6) & Very Fast \\
\hline
\end{tabular}

Figure 2 below is a Matlab simulink of lookup table for shipping feasibility.

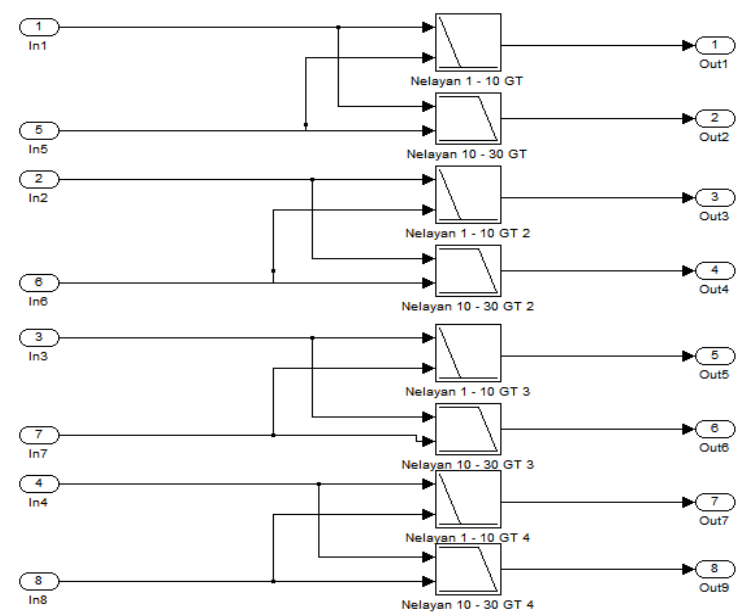

Figure 2: The simulink of Matlab software of shipping feasibility

\subsection{Simulation and Testing}

The research is done in 2 phases, ie simulation model, and real field implementation. Phase 1 is performed to obtain the best performance of predictor system in a high accuracy and it is not delay in data transmission. Phase 2 is performed to test before mass production system and ready to use in some coastal area in East Java. This research is done in part of phase 2. The information system of the marine weather to sent the fishermen use block diagram shown in Figure 3 below.

The maritime weather data are measured by the sensors at buoyweather and delivered to the ground stations by radio frequency. There are two servers on the ground, server 1 as data recorders, data processors, predictors and storage in online. Server 2 will send weather data in the present and result of predictors to users via the internet network. 


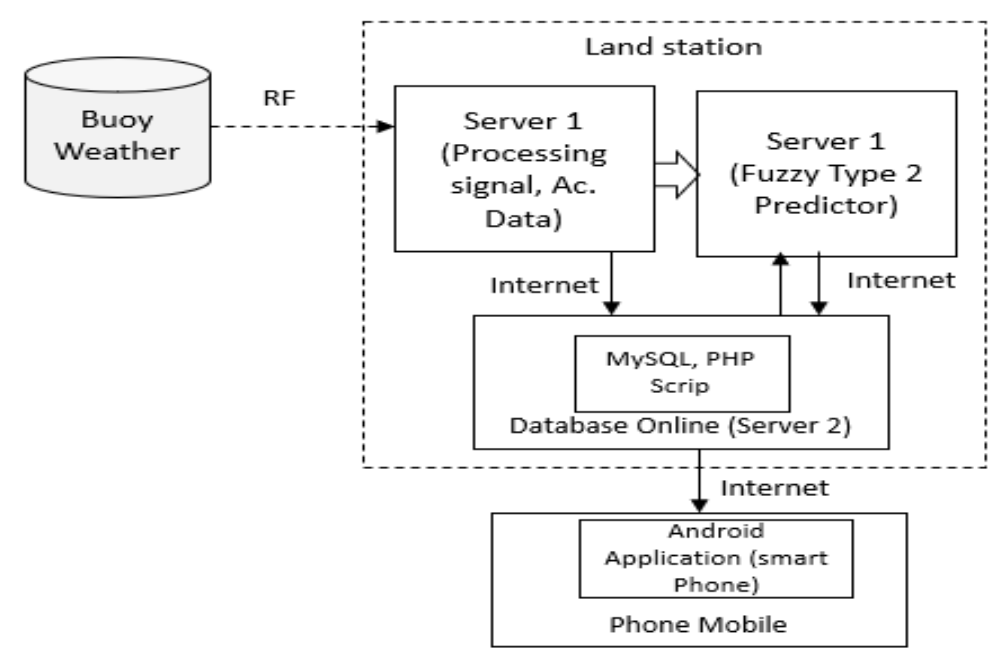

Figure. 3: Sytem diagram of transmition data from ground station to smartphone

\section{Results and Discussion}

\subsection{The Accuracy of Predictor}

The accuracy of predictor using fuzzy type 2 shows an improvement compared to the fuzzy type 1 and ANFIS. The Table 2 below shows the accuracy difference in many predictor methods. The accuracy of fuzzy type 2 shows the highest compared to other two methods. The fuzzy predictor type 2 performs in two-step process. After the inference mechanism is done in the fuzzy system, it will perform next step to reduce the interval and / or fuzzy membership function. Reducing step is formed through the intersection operation of the two value of membership function. This mechanism causes the result of inference / decision in a more precise value. The predictors of wind speed and sea current velocity use of Fuzzy and Fuzzy type 2 methods yielded in lower accuracy, while ANFIS was higher than to both. The accuracy in three methods are shown in Table III. The ANFIS method give a good accuracy for the 1 (one) hour later. The choosing ANFIS parameters in properly will improve the accuracy in predictor over of 5 hours later. The other methods, that are Fuzzy and Fuzzy Type 2 needs to be reconfigured or parameterized to improve its accuracy [19].

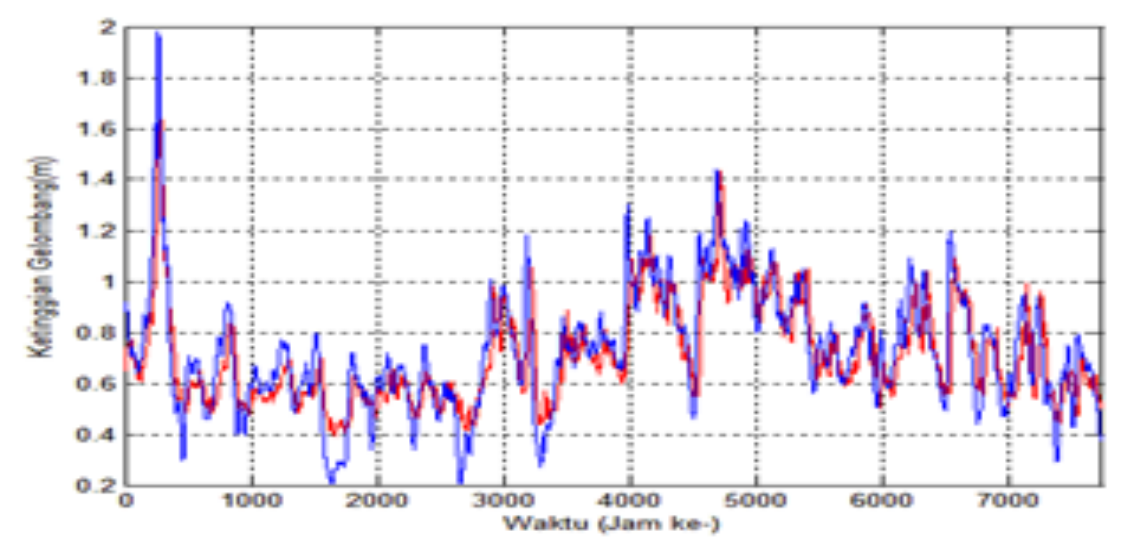

Figure 4: The actual and 24 hours later of Fuzzy 2 Predictors of significant wave height in Banyuwangi waters 
Table 2 shows the accuracy of wave height predictors using three methods, i.e: Fuzzy, ANFIS and Fuzzy Type 2. The Fuzzy type 2 method gives the higher accuracy than two others in several hour later, on the other hand the predictor of sea current and wind speed shows that ANFIS methods give the higher accuracy than other methods for both variables. It is shown in Table 3.

Table 2: The Accuracy of the Wave Height Predictors

\begin{tabular}{|c|c|c|c|}
\hline Prediction (in hour later) & Fuzzy $^{\mathrm{a}}$ & ANFIS $^{\mathrm{b}}$ & Fuzzy Type $^{\mathrm{c}}$ \\
\hline 1 & 91.250 & 96.538 & 98.600 \\
\hline 2 & 91.010 & 92.051 & 97.800 \\
\hline 3 & 90.980 & 88.974 & 97.300 \\
\hline 4 & 89.950 & 87.436 & 96.800 \\
\hline 5 & 89.920 & 83.077 & 96.400 \\
\hline 6 & 89.900 & 79.872 & 96.100 \\
\hline 7 & 89.780 & 76.538 & 95.800 \\
\hline 8 & 89.010 & 75.513 & 95.400 \\
\hline 9 & 88.310 & 72.179 & 95.200 \\
\hline 10 & 88.090 & 70.128 & 95.000 \\
\hline 11 & 87.960 & 68.462 & 94.800 \\
\hline 12 & 87.880 & 65.769 & 94.600 \\
\hline
\end{tabular}

Table 3: The Accuracy of the Current and Wind Predictors

\begin{tabular}{|c|c|c|c|c|c|}
\hline \multirow[t]{2}{*}{$\begin{array}{l}\text { Time of Prediction (in hour } \\
\text { later) }\end{array}$} & \multicolumn{2}{|c|}{$\begin{array}{c}\text { Accuracy of Sea } \\
\text { Current Predictor (\%) }\end{array}$} & \multicolumn{3}{|c|}{$\begin{array}{l}\text { Accuracy of Wind Speed Predictor } \\
\qquad(\%)\end{array}$} \\
\hline & Fuzzy $^{\mathrm{a}}$ & ANFIS $^{b}$ & Fuzzy $^{\mathrm{a}}$ & ANFIS $^{b}$ & $\begin{array}{c}\text { Fuzzy } \\
\text { Type } 2^{c}\end{array}$ \\
\hline 1 & 85.30 & 96.44 & 88.13 & 97.27 & 60.21 \\
\hline 6 & 64.64 & 92.47 & 57.74 & 83.03 & 31.23 \\
\hline 12 & 55.59 & 88.12 & 43.79 & 65.18 & 16.94 \\
\hline 24 & 48.70 & 85.32 & 36.75 & 61.44 & 12.53 \\
\hline
\end{tabular}

\subsection{Shipping Feasibility}

The shipping feasibility for sailing in the east Java waters is based on tonnage of vessels and sea conditions. The criteria of sailing is shown in Table I. Significant wave heights and ocean currents are used as input for decision-making system. The experiment is done in 4 area, ie Java Sea (Surabaya waters and Banjarmasin waters), Banyuwangi, Situbondo and Pasuruan waters. The tonnage of vessel in the waters is a maximum of 30 GT. Table IV shows the accuracy of result the decision system for shipping fishermen feasibility in 4 waters in Indonesia. 


\subsection{Data Transmission}

The testing in transmision data is done in some distance from the beach in Surabaya waters, that are: $10,25,50,75,100,125,150,175,200,225$ and 225 meters. The error of transmision is characterized by no losses data or the number of losses is $0 \%$. The testing data transmission in the number of Bits on the signal transmission of all-weather variables compared to the Bit Error Rate (BER). Theoretical error values are obtained from the ideal formula in BER theory. The percentage of transmision error data in five values of Signal to Noise Ratio (SNR) ie 0, 5, 10, 15, 20 and 25 DB, shown in Table V below.

Table 4: The Accuracy of Shipping Feasibility

\begin{tabular}{|c|c|c|c|c|c|c|}
\hline \multirow{2}{*}{$\mathrm{t}$} & $\mathrm{GT}$ & Banyuwangi & Situbondo & Pasuruan & $\begin{array}{c}\text { Java Sea } \\
\text { (Surabaya } \\
\text { waters) }\end{array}$ & $\begin{array}{c}\text { Java Sea } \\
\text { (Banjarmasin } \\
\text { waters) }\end{array}$ \\
\hline \multirow{2}{*}{1} & $1-10$ & 94.30 & 95.72 & 93.86 & 97.50 & 94.89 \\
\cline { 2 - 7 } & $10-30$ & 99.57 & 99.50 & 99.57 & 99.98 & 99.97 \\
\hline \multirow{2}{*}{6} & $1-10$ & 92.26 & 94.17 & 94.42 & 96.96 & 90.15 \\
\cline { 2 - 7 } & $10-30$ & 99.16 & 99.11 & 99.46 & 100.00 & 96.43 \\
\hline \multirow{2}{*}{12} & $1-10$ & 86.51 & 91.65 & 92.95 & 96.96 & 87.36 \\
\cline { 2 - 7 } & $10-30$ & 98.77 & 98.72 & 99.57 & 98.88 & 90.12 \\
\hline \multirow{2}{*}{24} & $1-10$ & 89.90 & 89.61 & 85.34 & 95.57 & 80.13 \\
\cline { 2 - 7 } & $10-30$ & 97.96 & 98.02 & 98.91 & 98.39 & 84.17 \\
\hline
\end{tabular}

Remark: t: time of prediction in hour later, GT: Gross Tonnage

Table 5: The Error of Transmition data in Maritime Predictors

\begin{tabular}{|c|c|c|c|c|c|c|}
\hline $\mathrm{SNR}(\mathrm{dB})^{\mathrm{a}}$ & 0 & 5 & 10 & 15 & 20 & 25 \\
\hline$\%$ Error & 7.60 & 0.63 & 0.00 & 0.00 & 0.00 & 0.00 \\
\hline
\end{tabular}

\section{Conclusion}

The wave height predictors used Fuzzy Type II gives the highest accuracy compared to Fuzzy and ANFIS methods. The other hand for predictor of wind speed and sea current, ANFIS more good than other as mention before. The average of percentage of accuracy of the shipping feasibility in five areas in Indonesia waters is over $80 \%$ for sailing recommendations on 24 hours later. The error of transmission and information system in sending maritime weather to the user via android smartphone is $7.6 \%$ and decreased to $0 \%$ when SNR larger $10 \mathrm{~dB}$.

\section{Acknowledgements}

Thanks to: Ministry Research, Technology, and Higher education in funding of the reseacrh in 2014, 2016, and 2017, also thanks to LPPM ITS, Laboratory of Hydrodinamics Surabaya, Laboratory of Instrumentation, Dept. Engineering Physics ITS, Laboratory of Hydrodynamics, Dept. of Naval Architecture ITS. 


\section{References}

[1] S. Arifin, G. Nugroho, and W. H. Nugroho, "Integrasi sistem buoyweather untuk membangun sistem informasi cuaca maritim di sub daerah WPP 712 - laut Jawa sebagai upaya peningkatan keselamatan nelayan Jawa Timur," Surabaya, 2016.

[2] E. Onyango, S. Ochieng, A. Awiti, E. Onyango, S. Ochieng, and A. O. Awiti, "Weather and climate information needs of small-scale farming and fishing communities in western Kenya for enhanced adaptive potential to climate change Weather and climate information needs of small-scale farming and fishing communities in western Kenya," in Proceedings of the 2012 Mechanical Engineering Conference on Sustainable Research and Innovation, 2014, no. January, pp. 187-193.

[3] S. Z. Omar and H. A. M. . Shaffril, "Weather forecasting as an early warning system: Pattern of weather forecast usage among coastal communities in Malaysia," Life Sci. J., vol. 10, no. 4, pp. 540-549, 2013.

[4] S. Dry, "Centre for analysis of risk and regulation fishermen and forecasts: How barometers helped make the meteorological department safer in Victorian Britain," no. October. pp. 1-33, 2007.

[5] S. Arifin, A. S. Aisjah, and B. Lelono, "Perancangan simulator peramal cuaca maritim untuk kelayakan pelayaran: studi kasus jalur Surabaya-Banjarmasin,” Surabaya, 2011.

[6] Badan Pembinaan Hukum Nasional Departemen Hukum Dan Hak Asasi Manusia RI, “Analisis evaluasi peraturan perundang-undangan tentang yurisdiksi dan kompetensi mahkamah pelayaran,” Jakarta, 2005.

[7] S. Arifin, G. Nugroho, and W. H. Nugroho, "Integrasi sistem buoyweather untuk membangun sistem informasi cuaca maritim di sub daerah WPP 712 - laut Jawa sebagai upaya peningkatan keselamatan nelayan Jawa Timur," Surabaya, 2014.

[8] S. dkk; Arifin, Laporan Akhir PUPT - Pengembangan desain stasiun cuaca laut dengan keandalan tinggi pada sea state 4. Surabaya, 2017.

[9] S. Arifin, A. S. Aisjah, G. Nugroho, and W. H. Nugroho, "Integrasi sistem buoyweather untuk membangun sistem informasi cuaca maritim di sub daerah WPP 712 - laut Jawa sebagai upaya peningkatan keselamatan nelayan Jawa Timur," Surabaya, 2015.

[10]N. Arifin, Syamsul; Aisjah, Aulia S.; Sabrina, "Optimization of buoyweather models use of PSO method: High Reliability in Java Sea as Maritim Weather Station, ” in International Conference On Marine Technology 2017, 2017, pp. 104-116.

[11]M. H. Kazeminezhad, “On the prediction of wave parameters using simplified methods, ” J. Coast. Res., vol. 56, pp. 505-509, 2009.

[12]S. Arifin, A. S. Aisjah, B. Lelono, and P. Meilanitasari, "Maritim weather forecast using fuzzy logic for shipping feasibility at Tanjung perak Port Surabaya," in SENTA 2010, 2010, no. 1, pp. 2-7.

[13]S. Arifin, A. S. Aisjah, and J. Al Hakim, "Interpolasi Lagrange dan Newton untuk peningkatan jangkauan ramalan prediktor cuaca maritim berdasarkan logika fuzzy, studi kasus:L di perairan Laut Jawa," in Seminar Nasional SENTA 2011, 2011, pp. X1-9.

[14]T. Hokimoto, "Provisional chapter A Statistical Approach for Wave-Height Forecast A Statistical Approach for Wave-Height Forecast Based Based on Spatiotemporal Variation of Surface Wind on Spatiotemporal Variation of Surface Wind," in Oceanography, 2013, pp. 1-20.

[15]H. Saima, J. Jaafar, S. Belhaouari, and T. A. Jillani, “ARIMA based Interval Type-2 Fuzzy Model for Forecasting,” Int. J. Comput. Appl., vol. 28, no. 3, pp. 17-21, 2011.

[16]L. Li, W. Lin, and H. Liu, "Type-2 fuzzy logic approach for short-term traffic forecasting," IEE Proc. online, vol. 153, no. 1, pp. 33-40, 2006.

[17]A. S. Aisjah and S. Arifin, "Maritime Weather Prediction Using Fuzzy Logic in Java Sea for Shipping Feasibility," Int. J. Artif. Intell., vol. 1-11, no. 5, 2013.

[18]T. I. Fossen, Handbook of Marine Craft Hydrodynamics and Marine Craft Hydrodynamics And. Norway: John Wiley \& Sons, 2011.

[19]Sulaiman, et al; “An Effective Fuzzy C-Mean And Type-2 Fuzzy,” J. Theor. Appl. Inf. Technol., pp. 556-567, 2009. 